\title{
Fairy Whisperer's March to the East
}

\author{
Review essay by Marija Bulatović and Višnja Krstić
}

Jelena J. Dimitrijević, Sedam mora i tri okeana: Putem oko sveta (Seven seas and three oceans: Traveling around the globe), edited by Biljana Dojčinović, Belgrade: Laguna, 2016, 445 pp., price not listed (paperback), ISBN 978-86-521-2306-3.

Jelena J. Dimitrijević, Pisma iz Indije (Letters from India), second edition, edited by Ana Stjelja, English translation by Željko V. Mitić, Hindi translation by Latika Chawda, Belgrade: A. Stjelja, 2017, 106 pp., price not listed (paperback), ISBN 978-86-918903-6-0.

Within the research project "Knjiženstvo-Theory and History of Women's Writing in Serbian until 1915," sponsored by the Serbian Ministry of Education, Science, and Technological Development, Professor Biljana Dojčinović has produced a revised edition of Jelena Dimitrijević's (1862-1945) travelogue, Sedam mora i tri okeana: Putem oko sveta (Seven seas and three oceans: Traveling around the globe), first published by Laguna in 2016 in the Serbian language. Although little known to a wider audience, author Jelena Dimitrijević, labeled on the cover as "the first Serbian female world traveler," is a fascinating figure, whose writings about -in many respects still exotic-landscapes and civilizations of the Middle East are worthy of closer consideration, insofar as they are a testimony to a turbulent period in the national histories of the people inhabiting these ancient regions.

Sedam mora i tri okeana: Putem oko sveta opens with Dojčinović's preface, "'Viloslovka' putem oko sveta" ("Fairy whisperer" traveling around the globe), which not only places the text in its cultural and historical context, but analyzes it, primarily in the light of feminist literary theory, thereby revealing some of the text's complexities to prospective readers. With a note that "only the necessary linguistic adaptations have been made to match contemporary orthography" (442), which refers mainly to punctuation interventions, this edition aims to preserve "the flavour of the time from which the author speaks to us" (442). A glossary of little-known words is provided at the end of the book (443-445); it contains sixty entries that specify the etymology as well as the meaning of the given words.

Written in the form of an epistolary diary, the travelogue Sedam mora i tri okeana: Putem oko sveta has a clear and concise style. Thematically, the book is divided into 
three sections: entitled respectively "From Genoa to Alexandria," "Across the Land of the Pharaohs," and "In the Holy Land and Syria." The travelogue begins with an entry written on 17 November 1926 in Genoa, mere hours before Jelena Dimitrijević set off on her journey "around the world." After having toured the territories that today belong to Egypt, where she visited Alexandria, Cairo, and Luxor, among other places, she traveled further, through the Suez Canal, to the Holy Land. Once there, she dedicated much of her attention to Jerusalem and nearby sites. The travelogue closes with chapters on Damascus, Beirut, and Haifa. Underpinned with carefully selected information on the history, geography, and ethnography of the region, as well as with various anecdotes and comparisons, this travelogue offers much more than mere descriptions. Longing for the unknown fills every page of the book, giving it a distinct lyrical tone. The cosmopolitan spirit of Jelena Dimitrijević is reflected in her expressions: the text abounds in multilingual insertions, most notably in English and French, but also in the languages of local communities.

Jelena Dimitrijević began her "march" to the East at the age of sixty-four. It is interesting that the author set off on her journey "around the world" shortly after recovering from a serious illness, which nearly impaired her eyesight. Narrated in Sedam mora i tri okeana, Dimitrijević's experience of traveling as "a woman of her age" (50) sets the basis for her examination of customary beliefs and for questioning the stereotypes common in her own society, where the "older lot" dare not travel on their own, for fear of "dying away from their home town" (48). This typical Balkan mindset is often contrasted with the views and experiences of those from other countries, especially England and the United States: similar to the author herself, the travelers from England and the US take little notice of obstacles imposed by their advanced age or by foreign countries and languages.

The adventures of Jelena Dimitrijević on this impressive journey, however, did not end in Haifa; she also traveled to the Far East, visiting India, China, and Japan. Therefore, these episodes from the travelogue Sedam mora i tri okeana: Putem oko sveta continue to emerge and develop in her other book - short epistolary notes, Pisma iz Indije (Letters from India), first published in 1928 in Belgrade. In 2017, almost 90 years after its first publication, Pisma iz Indije was reissued, edited by Dr. Ana Stjelja, ${ }^{1}$ a scholar who has been studying the literary work of this worldwide traveler and woman writer from Kruševac. ${ }^{2}$ This 2017 edition of Pisma was published in honor of the 155th anniversary of Jelena Dimitrijevićs birth and also in honor of the 90th anniversary of her encounter with the Bengali poet Rabindranath Tagore. It serves as a reminder of the literary and cultural significance of the text, and includes the editor's comments and parallel translations into English and Hindi (Devanagari script) as a kind of readership curiosity, enabling Jelena Dimitrijević's oeuvre to become more accessible and read far beyond Serbia.

Pisma iz Indije contains not only personal observations and autobiographical essay writings, but also acts as a testimony of the ethos and modus vivendi of the people with whom, although geographically and culturally distant, the Serbian author found a spiritual liaison. The travelogue consists of two epistolary records from Madras sent to unspecified addressees, more precisely to women students, or to young girls. The English translation of Pisma is precise, distinctly following the thought of the poetic 
self, although its transposition into another language creates certain disadvantages essentially marked by the prosodic and lexical boundaries of the language. The Hindi version is essentially translated from the English, so it would be advisable in the future for Hindi language experts to comment on the quality of this translation, considering that a semantic transfer is not separate from the understanding of culture.

In the first letter, the author portrays her "march" to India precisely on 11 March 1927, sketching her first contact with the Indian soil, the people, their habits, and customs. Picturesque descriptions that follow her inner state and excitement demystify the textual construct and topos (commonplace) of the Eastern culture. The first letter suggests the narrator's immense desire to meet Rabindranath Tagore and serves as an overture to the second - slightly longer-letter that reconstructs the encounter of these two poetic souls in India. The second letter, dated 12 March 1927, contains a detailed description of her first visit of a holy temple, as well as discussions about colonialism and current affairs in India. All these intricate descriptions, observations, seemingly subsidiary events and details form "the frame around the spiritual character of Tagore, just as those various gods and deities in the form of humans and animals in Hindu temples are a frame around the sacred being of Brahma" (59). Nevertheless, it seems that Jelena Dimitrijevićs fascination with the peculiar and unbridled India is the strongest feeling that the reader finds throughout the stylistically nuanced fragments of the text. The feeling of belonging to India gradually turns into a draft of women's phenomenology, bearing in mind that the author, on a number of occasions, refers to the Indian country as a mother.

The feminist aspect in Sedam mora i tri okeana: Putem oko sveta, which has captured close academic attention in previous decades, is evident from the very first chapter, where Jelena Dimitrijević dedicates her book to no one else but to women. Indeed, Sedam mora $i$ tri okeana is interspersed with contemplations of the rather inequitable status of women in different parts of the world, from ancient until modern times. It is through a feminist perspective, which is present, inter alia, in the descriptions of the localities and apparently harmless local practices that the author points toward the subtle mechanisms of women's subordination. In this light, of particular interest are the numerous parallels that Dimitrijević draws between recently modernized Turkey and still strictly patriarchal Egypt. An entire chapter is dedicated to the author's meeting with Huda Sha'arawi, a prominent Egyptian feminist at the time, who advocated for women's right to vote in her country. However, the importance of this encounter in Sedam mora i tri okeana stands parallel to the author's visit to Bengali poet Tagore in Pisma. Tagore, visibly ill, receives Dimitrijević in a kind and devoted manner, recalling the "Slavic hospitality" (54) he experienced during his stay in Belgrade. Although the central narrative in Pisma represents the encounter with Tagore, the key image becomes the narrator's kaleidoscopic representation of the East through the image of the Bengali poet, sophisticated observations, and disenchantment of the literally petrified topos of the East: "It's not the way I have read or heard about it" (37).

What makes both of these travelogues truly stand out from the plethora of similar texts is the author's critical commentary on different aspects of the societies that she encounters, including their customs, tradition, mythology, religion, politics, education, as well as social and gender differences. Mango trees and coconut palm trees in 
hot air, screaming monkeys and women lightly dressed in traditional saris are just some of the details in Pisma that bring readers closer to the importance of the home of Tagore as a spiritual center, the symbol of India and Bengali poetry itself. The image of India presented in Pisma is a part of the oriental mosaic constructed with simple style and short sentences. Poetic comparisons, unusual word disposition, and choice of words emphasizing authentic sentimentality and excitement are consequently followed by sporadic redundancy in expression.

The contemporary reader of Jelena J. Dimitrijević's travelogues is given a hint of the author's creativity that has long been neglected. Even though widening and redefining a national canon is an incredibly slow process, hope remains that the reviewed travelogues will manage to excite the attention of a wider audience to Dimitrijevićs oeuvre beyond the confines of academia. The reissue of her Pisma is a strong reminder to reconsider all other works by Jelena J. Dimitrijević-novels, essays, travelogues, and poems. A liberal and a fighter not just for women's rights but for the rights of various oppressed groups, her works gave voice to many of those dwelling on the margins. It seems the time has come for us to give to this "fairy whisperer" back her own voice, which has been unfairly silenced in an odd mixture of political and ideological aspects.

\section{$\diamond$ About the Authors}

Marija Bulatović (1990) is a PhD student at the Faculty of Philology, University of Belgrade. She holds a BA and an MA in comparative literature and literary theory from the University of Belgrade. She has been awarded scholarship from Fund for Young Talents and a high honors award of recognition from the Faculty of Philology for the exceptional success during her undergraduate studies. She is involved in the project of the Serbian Ministry of Education, "Knjiženstvo - Theory and History of Women's Writing in Serbian until 1915." Research interests include philosophy of art, aesthetics, French literature, and French contemporary literary theory. E-mail: bmarija90@gmail.com.

Višnja Krstić (1991) is a PhD student at the Faculty of Philology, University of Belgrade. She holds an MA in English literature from the University of Warwick as well as an MA and a BA in English language and literature from the University of Belgrade. She has been awarded scholarships from Harvard University's Institute for World Literature, the British Comparative Literature Association, the British Association for Slavonic and East European Studies, and the Serbian Ministry of Youth and Sports. She is involved in the project "Knjiženstvo-Theory and History of Women's Writing in Serbian until 1915." She is also the author of a review in Oxford Comparative Criticism and Translation Review. Research interests include translation, multilingualism, and feminism. E-mail: visnjakrstic@gmail.com.

\section{$\diamond$ Notes}

1. Dr. Ana Stjelja received her doctorate in 2012 at the Faculty of Philology at the University of Belgrade on the topic "Traditional and Modern Elements in the Work of Jelena Dimitrijević."

2. Kruševac is a city in central Serbia. 